\title{
KONSEP DAKWAH MASYARAKAT MULTIKULTURAL DENGAN MENELADANI AJARAN AL-QUSYAIRI DALAM TASAWUF AKHLAQI
}

\author{
Khoirul Anwar 1) \\ 1) Institut Agama Islam Sunan Kalijogo Malang \\ 1) khoirulanwar@iaiskjmalang.ac.id
}

\begin{abstract}
Abstrak: Tasawuf yang dianut dan diajarkan oleh al-Qusyairi adalah tasawuf yang sejalan dengan ajaran syariat. Dari tulisan-tulisannya terlihat bahwa ia berupaya menyadarkan orang bahwa tasawuf yang benar adalah tasawuf yang bersandarkan pada akidah yang benar dan tidak menyalahi ketentuan syariat, seperti yang dianut oleh para salaf atau Ahl al-Sunnah,. Dalam perspektif al-Qusyairi, pemurnian tauhid sangatlah prinsip dan urgen, karena Islam dibangun di atas kekuatan tauhid, bahkan kekuatan Islam justru terletak pada fondasi tauhid. Apabila tauhid yang dimiliki oleh umat Islam kuat, maka agama Islam menjadi kuat dan tangguh. Tauhid adalah kekayaan yang terbesar yang dimiliki oleh umat Islam, sekaligus sebagai senjata yang ampuh dalam menghadapi berbagai rongrongan hawa nafsu.

Dalam hal ini tasawuf yang diteladani adalah tasawuf akhlaqi yaitu kajian ilmu yang sangat memerlukan praktik untuk menguasainya. Tidak hanya berupa teori sebagai sebuah pengetahuan, tetapi harus dilakukan dengan aktifitas kehidupan manusia. Di dalam diri manusia juga ada potensi-potensi atau kekuatan-kekuatan. Ada yang disebut dengan fitrah yang cenderung kepada kebaikan. Ada juga yang disebut dengan nafsu yang cenderung kepada keburukan. Jadi, tasawuf akhlaqi yaitu ilmu yang memperlajari pada teori-teori perilaku dan perbaikan akhlak. tasawuf akhlaqi mempunyai tahap sistem pembinaan akhlak yaitu takhalli, tahalli dan tajalli
\end{abstract}

\section{Kata Kunci: Tasawuf, Tasawuf Akhlaqi}

\begin{abstract}
Sufism that is adhered to and taught by al-Qusyairi is Sufism which is in line with the teachings of Sharia. From his writings, it can be seen that he tries to make people aware that the true Sufism is Sufism which is based on the correct faith and does not violate the provisions of the Shari'a, as practiced by the salaf or Ahl al-Sunnah. In the perspective of alQusyairi, purification of monotheism is very important and urgent, because Islam is built on the power of monotheism, even the power of Islam lies on the foundation of tawhid. If the monotheism possessed by Muslims is strong, then Islam will become strong and resilient. Tawhid is the greatest wealth possessed by Muslims, as well as a powerful weapon in dealing with various undermines of lust.

In this case Sufism that is being exemplified is tasawuf akhlaqi, namely the study of science that really requires practice to master it. Not only in the form of theory as knowledge, but it must be done with the activities of human life.

In human beings there are also potentials or powers. There is something called nature which tends to goodness. There is also such a thing as lust which tends to evil. So, tasawuf akhlaqi is the science that studies the theories of behavior and moral improvement. tasawuf akhlaqi has a system of moral development, namely takhalli, tahalli and tajalli.
\end{abstract}

Keywords: Sufism, Sufism Akhlaqi 


\section{PENDAHULUAN}

Dalam wacana ilmu tasawuf, dibedakan adanya tiga corak atau aliran pemikiran sufisme, yaitu: Tasawuf akhlaqi, tasawuf amali dan tasawuf filosofis atau falsafi. Kemudian pembagian tiga corak ini disingkat oleh Prof. H.A. Rivay Siregar menjadi dua aliran yaitu tasawuf sunni (gabungan antara tashawwuf akhlaqi dan tashawwuf amali) dan tashawwuf filosofi. Keduanya mempunyai sejumlah kesamaan yang prinsipil di samping perbedaan-perbedaan yang mendasar. Persamaannya adalah bahwa keduanya mengaku bersumber dari al-Qur'an dan Sunnah dan sama-sama berjalan dalam maqâmât dan ah wâl. Perbedaanya adalah mengenai kedekatan antara sufi dengan Tuhannya. Penganut tasawuf sunni mengatakan bahwa sedekat apapun antara seorang manusia dengan Tuhannya tidak mungkin tumbuh karena tidak satu esensi. Sedangkan penganut tasawuf filosofis mengatakan bahwa manusia berpadu dengan Tuhan karena manusia tercipta dari esensi-Nya.

Selain itu perbedaan bersumber dari perbedaan instrumen yang digunakan dalam memecahkan persoalan. Di satu pihak, tasawuf sunni cukup menggunakan dalildalil naql dari ajaran Islâm, cenderung ortodoks dan sederhana dalam pemikiran. Di lain pihak tasawuf filosofis sangat gemar terhadap ide-ide spekulatif dengan menggunakan analisis filsafat yang mereka kuasai, baik filsafat Timur maupun Barat. ${ }^{1}$

Secara garis besar, Para ahli membagi akhlaq tasawuf menjadi dua aliran besar (kecendrungan). Pertama, kecendrungan tasawuf yang lebih mengarah pada teori-teori perilaku; dan kedua, kecenderungan tasawuf yang lebih mengarah pada perumusan teori-teori rumit, pemikiran spekulatif berbau filsafat serta memperlukan pemahaman mendalam. Kecenderungan pertama sering disebut dengan aliran tasawuf akhlaqi. Sedangkan kecenderungan kedua sering disebut dengan jenis aliran tasawuffalsafi. Kali ini pembahasan akan difokuskan pada tasawuf akhlaqi.

Tasawuf adalah suatu ilmu dengan diketahui hal ihwal kebaikan dan keburukan jiwa, cara membersihkannya dari tercela dan mengisinya dengan sifat-sifat yang terpuji

\footnotetext{
${ }^{1}$ Santri KH. Sholeh Bahruddin Sengonagung Purwosari Pasuruan, Sabilus Sâlikin, Jalan Para Sâlik
} (Ensiklopedi Tharîaah/Tashawwuf) (Pasuruan: Pondok Pesantren NGALAH, 2012). 
cara melakukan suluk, dan perjalanan menuju (keridhaan) Allah dan meninggalkan (larangan-larangan-Nya) menuju kepada (perintah-Nya). ${ }^{2}$

Tasawuf adalah nama lain dari "Mistisisme dalam Islam". Di kalangan orientalis Barat dikenal dengan sebutan "Sufisme", tasawuf bertujuan untuk memperoleh suatu hubungan khusus langsung dari Tuhan. Hubungan yang dimaksud mempunyai makna dengan penuh kesadaran, bahwa manusia sedang berada di hadirat Tuhan. ${ }^{3}$

Tasawuf akhlaqi memiliki sederetan tokoh terkenal, antara lain Hasan Al-Bashri (21-110 H/ 632-728 M), al-Harits bin Asad al-Muhasibi (w. 243 H), al-Qusyairi (w. 465 H) dan al-Ghazali (450-505 H/ 1058-1111).

Dari beberapa tokoh tersebut, pemakalah ingin mengakaji lebih dalam salah satu tokoh yaitu Al-Qusyairi, karena kitab Risalah Qusyairiyah karangan beliau banyak dijadikan sebagai rujukan utama bagi para ulama' yang terjun di dunia tasawuf, serta menjadi jawaban atas fenomena yang terjadi pada zaman tersebut berupa pelencengan nilai-nilai agama yang mengatas namakan tasawuf.

\section{METODE PENELTIAN}

Penelitian ini adalah penelitian kualitatif yang bersifat studi pustaka (library research) yang menggunakan buku-buku dan literatur-literatur lainnya sebagai objek yang utama. Jenis penelitian yang digunakan adalah kualitatif, yaitu penelitian yang menghasilkan informasi berupa catatan dan data deskriptif yang terdapat di dalam teks yang diteliti.

Dengan penelitian kualitatif, perlu dilakukan analisis deskriptif. Metode analisis deskriptif memberikan gambaran dan keterangan yang secara jelas, objektif, sistematis, analitis dan kritis mengenai nilai-nilai tasawuf dari Imam Qusyairi. Pendekatan kualitatif yang didasarkan pada langkah awal yang ditempuh dengan mengumpulkan data-data yang dibutuhkan, kemudian dilakukan klasifikasi dan deskripsi.

\footnotetext{
${ }^{2}$ Rosidi, “Konsep Maqomat Dalam Tradisi Sufistik KH. Ahmad Asrori Al-Ishaqy," Jurnal Tasawuf dan Pemikiran Islam Vol. 4, no. 1 Juni (2014): 29-55.

3 Mansur Fauzi, "TASAWUF (MISTISISME)," last modified 2018, http://mohmansurfauzi.blogspot.com/2016/11/tasawuf-mistisisme.html.
} 


\section{PEMBAHASAN}

\section{A. Perkembangan Tasawuf}

Secara keilmuan, tasawuf adalah disiplin ilmu yang baru dalam syari'at Islam, demikian menurut Ibnu Khaldun. Adapaun asal-usul tasawuf menurutnya adalah konsentrasi ibadah kepada Allah, meninggalkan kemewahan dan keindahan dunia dan menjauhkan diri dari Makhluk. Ketika kehidupan materialistik mulai mencuat dalam peri kehidupan masyarakat muslim pada abad kedua dan ketiga hijriyyah sebagai akibat dari kemajuan ekonomi di dunia Islam, orang-orang yang konsentrasi beribadah dan menjauhkan diri dari hiruk pikuknya kehidupan dunia disebutlah kaum sufi.

Berbeda dengan Ibnu Khaldun, Muhammad Iqbal dalam bukunya "Tajdid alFikr ad-Dini al-Islam" berpendapat bahwa tasawuf telah ada semenjak Nabi. Riyadoh Diniyyah telah lama menyertai kehidupan manusia sejak awal-awal Islam bahkan kehidupan ini semakin mengental di dalam sejarah kemanusiaan.

Menurut sebagian fakar, Imam Ali bin Abi Thalib adalah orang pertama yang memunculkan istilah taswuf. Menurut yang lain Salman al-Farisi.

Akar-akar tasawuf dalam Islam merupakan penjabaran dari ihsan. Ihsan sendiri merupakan bagian dari trilogi ajaran Islam. Islam adalah satu kesatuan dari iman, islam dan ihsan. Islam adalah penyerahan diri kepada Allah secara zahir, iman adalah I'tikad batin terhadap hal-hal gaib yang ada dalam rukun iman, sedangkan ihsan adalah komitmen terhadap hakikat zahir dan batin.

Tasawuf berasal dari kata Ash-shuf (Arab) yang berarti bulu / kain wol yang kasar. Nabi SAW bersabda “ Hendaklah kamu memakai baju bulu, agar memperoleh manisnya iman dalam hatimu". Tasawuf juga berasal dari kata Ahl ash-shuffah yang berarti kelompok sahabat yang tidak punya tempat tinggal dan tinggal diserambi masjid.

Tasawuf berasal dari tiga huruf sha, wawu dan fa yang secara etimologi berarti bersih atau suci, sedangkan menurut istilah terjadi beberapa pendapat, Imam Junaid al Bahgdaty mendefinisikan Tasawuf sebagai berikut: "mengambil setiap sifat baik dan meningalkan setiap sifat yang rendah". Menurut Ibrahim Bin Halal tasawuf 
adalah memeilih jalan hidup secara zuhud yaitu menjauhkan diri dari perhiasan hidup dengan berbagai bentuk kemewahan dunia.

Al Sadzily sufi besar dari Afrika Utara mendefisikanya tasawuf sebagai berikut: "praktik dan latihan diri melalui cinta yang dalam serta ibadah untuk mengembalikan diri pada jalan tuhan". Sedangkan Hasan Al-Bashri, memberikan pengertian Tashawwuf adalah senang dalam beribadah, mengerahkan kesunguhsungguhan dan meninggalkan kesibukan perkara yang tidak ada gunanya. Dan banyak lagi istilah-istilah yang saya kira tidak perlu saya paparkan, karena inti dari pada definisi tasawuf adalah "penyucian batin atau hati dan menjaganya dari hal-hal yang buruk, yang akan melahirkan perilaku hubungan yang harmonis dengan Sang Pencipta dan segenap Mahkluk. ${ }^{4}$

\section{B. Pengertian Tasawuf Akhlaqi}

Secara etimologis, tasawuf akhlaqi bermakna membersihkan tingkah laku atau saling membersihkan tingkah laku. Jika konteksnya adalah manusia, tingkah laku manusia menjadi sasarannya. Tasawuf akhlaqi ini bisa dipandang sebagai sebuah tatanan dasar untuk menjaga akhlak manusia, atau dalam bahasa sosialnya, yaitu moralitas masyarakat.

Oleh karena itu, tasawuf akhlaqi merupakan kajian ilmu yang sangat memerlukan praktik untuk menguasainya. Tidak hanya berupa teori sebagai sebuah pengetahuan, tetapi harus dilakukan dengan aktifitas kehidupan manusia.

Di dalam diri manusia juga ada potensi-potensi atau kekuatan-kekuatan. Ada yang disebut dengan fitrah yang cenderung kepada kebaikan. Ada juga yang disebut dengan nafsu yang cenderung kepada keburukan. Jadi, tasawuf akhlaqi yaitu ilmu yang memperlajari pada teori-teori perilaku dan perbaikan akhlak. tasawuf akhlaqi mempunyai tahap sistem pembinaan akhlak disusun sebagai berikut:

\section{a. Takhalli}

Takhalli merupakan langkah pertama yang harus di lakukan oleh seorang sufi. Takhalli adalah usaha mengosongkan diri dari perilaku dan akhlak tercela.

\footnotetext{
${ }^{4}$ Zuherni AB, "Sejarah Perkembangan Tasawuf," Substantia 13, no. 2 (2011): 249-256.
} 
Salah satu dari akhlak tercela yang paling banyak menyebabkan akhlak jelek antara lain adalah kecintaan yang berlebihan kepada urusan duniawi.

\section{b. Tahalli}

Tahalli adalah upaya mengisi dan menghiasi diri dengan jalan membiasakan diri dengan sikap, perilaku, dan akhlak terpuji. Tahapan tahalli dilakukan kaum sufi setelah mengosongkan jiwa dari akhlak-akhlak tercela. Dengan menjalankan ketentuan agama baik yang bersifat eksternal (luar) maupun internal (dalam). Yang disebut aspek luar adalah kewajiban-kewajiban yang bersifat formal seperti sholat, puasa, haji dll. Dan adapun yang bersifat dalam adalah seperti keimanan, ketaatan dan kecintaan kepada Tuhan

\section{c. Tajalli}

Untuk pemantapan dan pendalaman materi yang telah dilalui pada fase tahalli, maka rangkaian pendidikan akhlak selanjutnya adalah fase tajalli. Kata tajalli bermakna terungkapnya nur ghaib. Agar hasil yang telah diperoleh jiwa dan organ-organ tubuh -yang telah terisi dengan butir-butir mutiara akhlak dan sudah terbiasa melakukan perbuatan-perbuatan yang luhur- tidak berkurang, maka rasa ketuhanan perlu dihayati lebih lanjut. Kebiasaan yang dilakukan dengan kesadaran optimum dan rasa kecintaan yang mendalam dengan sendirinya akan menumbuhkan rasa rindu kepada-Nya. ${ }^{5}$

\section{Riwayat Hidup Al-Qusyairi}

\section{a. Biografi Al-Qusyairi}

Nama lengkap al-Qusyairi adalah Abdul Karim ibn Hawazin ibn Abdul Malik ibn Thalhah bin Muhammad, nama kun-yahnya Abul Qasim. Beberapa gelar yang disandang oleh al-Qusyairi yaitu :

pertama, An-Naisaburi, sebuah gelar yang dinisbatkan pada nama kota Naisabur atau Syabur, salah satu ibu kota terbesar negara Islam pada abad pertengahan, di samping kota Balkh-Harrat dan Marw.

\footnotetext{
${ }^{5}$ Rima Ronika, "CORAK AJARAN TASAWUF DALAM PÊPALI KI AGÊNG SELO DITINJAU DARI PERSPEKTIF HERMENEUTIK FRIEDRICH DANIEL ERNST SCHLEIERMACHER," Jurnal filsafat dan pemikiran islam Vol. 19, no. 2 Juli (2019).
} 
Kedua, al-Qusyairi, nama Qusyairi adalah sebutan marga Sa'ad al-Asyirah al-Qahthaniyah. Mereka adalah sekelompok orang yang tinggal di pesisiran Hadramaut.

Ketiga, al-Istiwa, orang-orang yang datang dari bangsa Arab yang memasuki daerah Khurasan dari daerah Ustawa, yaitu sebuah negara besar di wilayah pesisiran Naisabur, yang berhimpitan dengan batas wilayah Nasa.

Keempat, Asy-Syafi'i sebuah penisbatan nama pada madzhab Syafi'i yang didirikan oleh al-Imam Muhammad ibn Idris ibn Syafi'i pada tahun 150-204 H/767-820 M.

Kelima, al-Qusyairi memiliki gelar kehormatan, antara lain: al-Imam, alUstadz, asy-Syaikh, Zainul Islam, al-Jami' baina Syari'ati wa al-Haqiqah (perhimpunan antara nilai syariat dan hakikat). Gelar-gelar ini diberikan sebagai wujud penghormatan atas kedudukan yang tinggi dalam bidang tasawuf dan ilmu pengetahuan di dunia Islam.

Al-Qusyairi lahir di Astawa pada bulan Rabi'ul Awal tahun 376 H/986 M. Ia mempunyai garis keturunan dari pihak ibu berporos pada moyang atau marga Sulami, paman dari pihak ibu, Abu Aqil al-Sulami termasuk para pembesar yang menguasai daerah Ustawa. Marga Al-Sulami sendiri dapat ditarik dari salah satu bangsa, yaitu : al-Sulami yang menisbatkan pada Sulaim dan al-Sulami yang dinisbatkan pada bani Salamah. Ia meninggal di Naisabur, Ahad pagi tanggal 16 Rabi'ul Akhir tahun 465 H/1073 M. Ketika beliau berumur 87 tahun. Jenazah beliau disemayamkan di sisi makam gurunya, Syaikh Abu Ali al-Daqaq. Beliau menjadi yatim ketika masih kecil, kemudian diasuh oleh Abul Qasim al-Yamany, sahabat karib keluarga Qusyairi.

Pada masa itu, kondisi pemerintahan tidak berpihak pada kepentingan rakyat. Pada penguasa dan staf-stafnya berlomba-lomba memperberat tingkat pungutan pajak. Hal ini sangat mempengaruhi pertumbuhan jiwa beliau untuk bercita-cita meringankan beban dari masyarakat. Beliau berpikiran pergi ke Naisabur untuk belajar hitung yang berkaitan pajak. Naisabur pada saat itu berposisi sebagai ibu kota Khurasan yang sebelumnya merupakan pusat tempat para ulama dan pengarang serta para pujangga. 
Sesampainya di Naisabur beliau belajar berbagai ilmu pengetahuan pada seorang guru yang dikenal sebagai Imam yaitu Abu Ali al-Hasan ibn Ali alNaisabur dan lebih dikenal dengan al-Daqaq. Semenjak pertama kali mendengar fatwanya, beliau sudah mengaguminya. Sementara Syaikh al-Daqaq sendiri juga berfirasat bahwa pemuda ini seorang murid yang cerdas dan brilian. Karena itu, Syaikh al-Daqaq bermaksud mengajari dan menyibukkannya dengan berbagai bidang ilmu. Kenyataan ini membuat beliau mencabut cita-citanya semula, membuang pikiran yang berencana menguasai peran pemerintahan dan memilih thariqah sebagai garis perjuangan.

Beliau menikah dengan Fatimah, putri guru sejatinya (al-Daqaq). Dia seorang wanita berilmu, beradab, dan termasuk ahli zuhud yang diperhitungkan di zamannya. Beliau hidup bersamanya semenjak tahun 405 H/1014 M - 412 H/1021 M dan meninggalkan enam orang putra dan seorang putri. Kesemuanya adalah ahli ibadah. Al-Qusyairi berangkat haji dengan ulama-ulama terkemuka yang sangat dihormati pada waktu itu, di antaranya adalah Syaikh Abu Muhammad Abdullah ibn Yusuf al-Juwainy, salah seorang ulama tafsir, bahasa dan fiqh.

Beliau termasuk orang yang pandai menunggang kuda. Kepiawaiannya telah dibuktikan dalam berbagai lapangan pacuan kuda. Beliau juga seorang yang tangkas memainkan senjata. Permainannya benar-benar sangat mengagumkan. Ia mempunyai seekor kuda pemberian teman akrabnya, dan menggunakannya selama 20 tahun. Ketika beliau meninggal, kudanya ini sangat sedih, selama seminggu kuda tersebut tidak mau makan, sehingga akhirnya kuda tersebut meninggal karena sedih dan lapar.

Selain Abu Ali al-Hasan ibn Ali al-Naisaburi al-Daqaq. Al-Qusyairi pun mempunyai beberapa guru, antara lain: (1). Abu Abdurrahman Muhammad ibn al-Husin ibn Muhammad al-Azdi al-Sulami al-Naisaburi (325 H/936 M - 412 H/1012 M), seorang sejarahwan, ulama sufi sekaligus pengarang. (2). Abu Bakar Muhammad ibn al-Husain ibn Furak al-Anshari al-Ashbahani, meninggal tahun 406 H/1015 M, beliau seorang imam usul fiqh. (3). Abu Ishaq Ibrahim ibn Muhammad ibn Mahran al-Asfarayaini meninggal tahun 418 h/1027 M, seorang 
cendekiawan bidang fiqh dan usul fiqh yang besar di daerah Isfarayain. Kepadanya beliau belajar Ushuluddin. (4). Abu Manshur aliah Abdur Qahir ibn Muhammad al-Baghdadi al-Tamimi al-Asfarayaini, meninggal tahun 429 H/1037 M, kepadanya beliau belajar madzhab Syafi'i.

Al-Qusyairi adalah seorang tokoh yang terkemuka pada abad kelima Hijriyah yang cenderung mengadakan pembaharuan, yakni dengan mengembalikan tasawuf ke landasan Al-Qur'an dan As-Sunnah yang merupakan ciri-ciri utama dari ajaran tasawuf sunni. Kedudukannya yang demikian penting, menginget karya-karyanya tentang para sufi dan tasawuf aliran sunni pada abadabad ketiga dan keempat Hijriyah, yang membuat terpeliharanya pendapat dan khazanah tasawuf pada masa itu, baik dari segi teoritis maupun praktis. Menurut Ibnu Khalikan, Al-Qusyairi adalah seorang tokoh yang mampu "mengkompromikan syariat dengan hakikat".

Dapat dikatakan, Al-Qusyairi terkenal karena ia menuliskan sebuah risalah tentang tasawuf, yang diberi nama Ar-Risalah al-Qusyairiah. Sebenarnya, kitab ini ditulis olehnya untuk golongan orang-orang sufi dibeberapa negara Islam dalam tahun $473 \mathrm{H}$, kemudian tersiar luas keseluruh tempat kerena isinya ditujukan untuk mengadakan perbaikan terhadap ajaran-ajaran sufi yang pada saat itu telah banyak menyimpang dari sumber hukum Islam. Karya tulis AlQusyairi yang paling terkenal dan hingga saat ini menjadi bahan bacaan wajib bagi para peminat tasawuf adalah Risalah al-Qusyairiyyah fi'Ilm at-Tasawufi.

Al-Qusyairi adalah tokoh yang senantisa mengamalkan ajaran tasawuf, sehingga dalam sebuah buku, Khamsyakhanuwi menyatakan bahwa terdapat tokoh-tokoh sesudah abad ketiga Hijriyah yang walaupun sedah wafat mereka terus meerus beramal dalam kuburnya seperti ketika masih hidup. Beberpa diantaranya adalah Syeik Junaid al-Baghdadi, Abu Yazid al-Bustami, Imam Syibli, Al-Qsyairi, Asy-Syibani dan masih banyak sekali yang lain bahkan sampai beriburibu.

Pada permulaannya, diktrin-doktrin tasawuf di ajarkan melalui tandatanda, sebagimana sekarang juga dilakukan terhadap bagian-bagian yang berisi okultisme. Mereka yang sudah mahir akan mampu berbicara satu sama lain 
dengan tanda-tanda, tanpa mengucapkan sebuah kata pun. Dzun Nun adalah orang yang pertama kali merumuskan doktrin-doktrinnya melalui kata-kata. Junaid dari Baghdad juga mensistematisasi hal yang sama. Abu Bakar Shibli adalah orang yang menyerukan hal serupa dari mimbar masjid. Sebagaimana juga Socrates yang menurunkan filsafatnya dari "langit" ke dunia. Hal serupa juga dapat ditemukan pada karya tulis Abul Qasim al-Qusyairi dalam risalahnya: Risala-i-Qusyairiyah fi ilm-ut-Tasawuf. ${ }^{6}$

\section{b. Karya-karya Al-Qusyairi}

Al-Qusyairi dapat mengarang dalam kitab-kitabnya yang berisi masalah tasawuf dan ilmu-ilmu Islam. Antara lain:

1) Ahkam al-Syar'i

2) Adab al-Shufiyah

3) Al-Arba'un fi al-Hadits

4) Istifadhah al-Muradat

5) Balaghah al-Maqashid fi al-Tasawuf

6) At-Tahbir fi Tadzkir

7) Tartib al-Suluk, fi Thariqillahi Ta'ala

8) Al-Tauhid al-Nabawi

9) At-Taisir fi 'Ilmi al-Tafsir

10)Al-Jawahir

11)Hayat al-Arwah dan al-Dalil ila Thariq al-Shalah

12)Diwan al-Syi'ri

13)Al-Dzikr wa al-Dzakir

14)Al-Risalah al-Qusyairiyah fi ‘Ilmi al-Tasawuf

15)Sirat al-Masayikh

16)Syarâh Asma al-Husna

17)Syikuyat Ahl al-Sunnah bi Hikayati ma Nalahun min al-Mihnah 18)Uyun al-Ajwibah fi Ushul al-Asilah

${ }^{6}$ Anisa Listiana, "Menimbang Teologi Kaum Sufi Menurut Al-Qusyairi Dalam Kitab Al-Risālah AlQusyairiyah," Kalam: Jurnal Studi Agama dan Pemikiran Islam Vol. 7, no. 1 Juni (2013): 201-216. 
19)Lathaif al-Isyarat

20)Al-Fushul fi al-Ushul

21)Al-Luma' fi al-I'tiqad

22)Majalis Abi Ali al-Hasan al-Daqaq

23)Al-Mi'raj

24)Al-Munajah

25)Mantsuru al-Khitab fi Syuhub al-Albab

26)Nasikhu al-Hadits wa Mansukhuhu

27)Nahw al-Qulub al-Shaghir

28)Nahw al-Qulub al-Kabir

29)Nukatu Uli al-Nuha

\section{c. Pemikiran Al-Qusyairi}

1. Mengembalikan Tasawuf ke Landasan Ahlussunnah

Seandaikan karya Al-Qusyairi, Ar-Risalah al-Qusyairi dikaji secara mendalam, akan tampak jelas bagaimana dia cenderung mengembalikan tasawuf ke atas landasan doktrin Ahlus Sunnah, sebagimana pernyatannya, "ketauhilah! Para tokoh aliran ini (maksudnya para sufi) membina prinsipprinsip tasawufatas landasan tauhidyang benar, sehingga terpeliharah doktrin mereka dari penyimpangan. Selain itu, mereka lebih dekat dengan tauhid kaum salaf maupun Ahlus Sunnah, yang tidak tertandingi serta mengenal macet. Mereka pun tahu hak yang lama, dan bias mewujudkan sifat sesuatu yang diadakan dari ketiadaannya. Karena itu, tokoh aliran ini, Al-Junaid mengatakan bahwa tauhid adalah pemisah hal yang lama dengan hal yang baru. Landasan doktrin-doktrin mereka pun di dasarkan pada dalil dan bukti yang kuat serta gamblang. Dan seperti dikatakan Abu Muhammad Al-Jariri bahwa barang siapa yang tidak mendasarkan ilmu tauhid pada salah satu pengokohnya, niscaya membuat tergelincir kaki yang tertipu kedalam jurang kehancurannya.",

Secara implisit dalam ungkapan Al-Qusyairi tersebut terkandung penolakan terhadap para sufi syathahi yang mengucapkan ungkapanungkapan penuh kesan terjadinya perpaduan antara sifat-sifat ketuhanan, 
khususnya sifat terdahulu-Nya, dengan sifat-sifat kemanusiaan, khususnya sifat baharunya. Bakan dengan konotasi lain, secara terang-terangan AlQusyairi mengkritik mereka,

"Mereka menyatakan bahwa mereka telah bebas dariperbudakan sebagai belenggu dan berhasil mencapai realita-realitas rasa penyatuan dengan Tuhan (wushul). Lebih jauh lagi, mereka tegak bersama Yang Maha Besar, dimana hukum-hukum-Nya berlaku atas diri mereka, sementar mereka dalam keadaan fana. Allah pun, menurut mereka tidak mencela maupun melarang apa yang mereka nyatakan ataupun lakukan. Dan kepada mereka disingkapkan rahasia-rahasia keesaan dan setelah fana, mereka pun tetap memperoleh cahaya-cahaya ketuhanan, tempatbergantung pada sesuatu...."

2. Selain itu, Al-Qusyairi pun mengecam keras para sufi pada masanya, karena kegemaran mereka mempergunakan pakaian orang-orang miskin, sementara tindakan mereka pada saat yang sama bertentangan dengan tindakan mereka. Ia menekankan bahwa kesehatan batin, dengan berpegang teguh pada Al-Quran dan As-Sunnah, lebuh penting ketimbang pakaian lahiriah. Sebagimana perkatannya,

"Duhai saudaraku! Janganlah kamu terpesona oleh pakaian lahiriah maupun sebutan yang kau lihat (pada para sufi sezamannya). Sebab, ketika hakikat realitas-realitas itu tersingkapkan, niscaya tampak keburukan para sufi yang megada-ada dalam berpakaian - setiap tasawufyang tidak dibarengi dengan kebersihan maupun penjauhan diri dari maksiat adalah tasawuf palsu serta memberatkan diri; dan setiap yang batin itu bertentangan dengan lahir adalah keliru dan bukannya yang batin... setiap tauhid yang tidak dibenarkan AlQur'an maupun As-sunnah adalah pengingkaran Tuhan dan bukan tauhid; setiap pengenalan terhadapa Allah yang tidak dibarengi kerendahan hati maupuin kelurusan jiwa adalah palsu dan bukannya pengenalan terhadap Allah."

3. Penyimpangan Para Sufi 
Dalam konteks yang berbeda, dengan ungkapan yang pedas, AlQusyairi mengemukakan suatu penyimpangan lain dari pada abad kelima Hijriah,

"Kebanyakan para sufi yang menempuh jalan kebenaran dari kelompok tersebut telah tiada. Dalam bekas mereka, tidak ada yang tinggal dari kelompok tersebut, kecuali bekas-bekas mereka."

Zaman telah berakhir bagi jalan ini. Tidak, bahkan jalan ini telah menyimpang dari hakikat realitas. Telah lewat zaman para guru yang menjadi panutan mereka. Tidak banyak lagi generasi muda yang mau mengikuti perjalanan dan kehidupan mereka. Sirnalah kerendahan hati dan punahlah sudah kesederhanaan hidup. Ketamakan semaki menggelora dan ikatannya semakin membelit. Hilanglah kehormatan harga dari kalbu. Betapa sedikit orang-orang yang berpegang teguh pada agama. Banyak orang yang menolak membedakan masalah halal haram. Mereka cenderung meninggalkan sikap menghormati orang lain dan membuang jauh rasa mau. Bahkan, mereka merasa enteng pelaksanaan ibadah, melecehkan puasa dan shalat, dan terbuai dalam medan kemabukan.dan mereka jatuh dalam pelukan nfsu suahwat dan tidak peduli sekalipun melakukan hal-hal yang tidak diperbolehkan......."

Pendapat Al-Qusyairi diatas barangkali terlalu berlebihan. Namun, apapun masalahnya, paling tidak, hal itu menunjukkan bahwa tasawuf pada masanya mulai menyimpang dari perkembangannya yang pertama, baik dari segi akidah atau dari segi-segi moral dan tingkah laku.

Oleh karena itu pula, Al-Qusyairi menyatakan bahwa ia menulis risalahnya karena dorongan rasa sedihnya melihat apa-apa yang menimpa jalan tasawuf. Ia tidak bermaksud menjelek-jelekkan salah seorang dari kelompok tersebut dengan mendasarkan diri pada penyimpangan sebagian penyerunya. Risalahnya itu, menurutnya, sekedar "pengobatan keluhan" atas apa yang menimpa tasawuf pada masanya.

Al-Qusyairi cenderung mengembalikan tasawuf ke atas landasan doktrin ahlu al-sunnah yaitu dengan mengikuti para sufi sunni pada abad 
ketiga dan keempat Hijriyah. Dia menolak terhadap sufi syathahi, yang menyatakan adanya perpaduan antara sifat-sifat ke-Tuhanan, khususnya sifat qodim-Nya, dan sifat-sifat kemanusiaan khususnya sifat hadis-Nya. Dari sini jelaslah bahwa Al-Qusyairi adalah pembuka jalan bagi kedatangan AlGhazali, yang berafiliasi pada aliran yang sama yaitu Al-Asy'ariyayah, yang nantinya akan merujuk paada gagasan Al-Qusyairi.

Dari uraian diatas, tampak jelas bahwa pengembalian arah tasawuf, munurut Al-Qsyairi harus dengan merujuknya pada doktrin Ahlussunnah Wal Jama'ah, yang dalam hal ini ialah dengan mengikuti para sufi Sunni pada abad-abad ketiga dan keempat Hijriah yang sebagaimana diriwayatkannya dalam Ar-Risalah.

Dalam hal ini, jelaslah bahwa Al-Qusyairi adalah pembuka jalan bagi kedatangan Al-Ghazali, yang dirafiliasi pada aliran yang sama, yaitu AlAsy'ariyah yang nanti akan merujuk pada gagasannya itu serta menempuh jalan yang dilalui Al-Muhasibi maupun Al-Junaidi, secara melancarkan kritik keras terhadap para sufi yang terkenal dengan ungkapan-ungkapan yang ganjil.

Selian dari ketiga hal diatas, Al-Qusyairi juga memberikan pandangannya kepada beberapa istilah yang ada dalam tasawuf, seperti fana' dan baqa', wara', syari'at dan hakikat:

a) Baqa' dan Fana'

Dalam struktul ahwal, yaitu mengenai fana' dan baqa', Al-Qusyairi mengemukakan bahwa fana' adalah gugurnya sifat-sifat tercela,sedangkan baqa' adalah jelasnya sifat-sifat terpuji. Barangsiapa fana' dari sifat-sifat tercela, maka yang tampak adalah sifat-sifat terpuji. Sebalikya, apabila yang dominan adalah sifat-sifat tercela maka sifat-sifat terpuji akan tertutupi. Jika seorang individu secara terus-menerus membersihkan diri dengan segala upayanya, maka Allah akan memberikan anugerah melelui kejernihan perilakunya, bahkan dengan penyempurnaan tingkah laku tersebut.

b) Wara' 
Pemikiran Al-Qusyairi yang lain adalah wara', menurutnya wara' merupakan usaha untuk tidak melakukan hal-hal yang bersifat syubhat (sesuatu yang diragukan halal haramnya). Bersikap wara' adalah suatu pilihan bagi ahli tarekat.

c) Syari'at dan Hakikat

Al-Qusyairi membedakan antara syari'at dan hakikat; hakikat itu adalah penyaksian manusia tentang rahasia-rahasia ke-Tuhanan dengan mata hatinya. Sedangkan syari'at adalah kepastian hukum dalam ubudiyah, sebagai kewajiban hamba kepada Al-Khaliq. Syari'at ditunjukkan dalam bentuk kaifiyah lahiriah antara manusia dengan Allah SWT.7

Tasawuf sebagai suatu ilmu yang telah berkembang semenjak pertengahan abad ke dua Hijriah hingga saat ini tentu mmengembangkan bahasa khusus yang hanya bisa dimengerti dalam kaitannya dengan ajaran dan penghayatan para sufi. Misalnya istilah "syari'at" bagi para sufi pengertiannya selalu di hubungkan dengan "hakikat". Maka menurut kacamata para sufi syari'at hanya diberi makna sebatas tingkah laku lahiriah menurut aturan-aturan formal dari pada agama. Jadi, tingkah laku batin seperti kekhusyukan jiwa dalam ibadah dan rasa dekat dengan Tuhan dalam shalat beserta etika itu tidak dimasukkan dalam istilah syari'at. Oleh karena itu, imam Al-Qusyari dalam risalahnya mengatakan:

"Maka setiap syari'ah tidak di dukung oleh hakikat tidak akan diterima. Dan setiap hakikat yang tak terkait dengan dengan syari'at tentu tidak ada hasilnya."

Dalam ajaran tasawuf atau kebatinan, hati manusia di percayai punya kemampuan rohani dan menjadi alat satu-satunya untuk ma'rifat pada Dzat Tuhan dan untuk mengenal sifat rahasia alam ghaib. Dalam hal ini, Al-Ghazali menjelaskan bahwa Dzat Tuhan itu sebenarnya terang benderang. Hanya karena terlalu terang maka tak tertangkap oleh mata manusia. Mata

${ }^{7}$ Santri KH. Sholeh Bahruddin Sengonagung Purwosari Pasuruan, Sabilus Sâlikin, Jalan Para Sâlik (Ensiklopedi Tharîqah/Tashawwuf). 
manusialah yang tak mampu menangkap Dzat Tuhan. Dalam hal ini, AlRisalah al-Qusyairi lebih memperinci lagi. Dia menyatakan bahwa di dalam qalbu terdapat ruh dan sir. Seterusnya sir dikatakan sebagai tempat menyaksikan atau gaib, dan ruh merupakan tempat mencintai Tuhan dan qalbu adalah tempat untuk ma'rifat kepada Dzat Tuhan.

Karangan Al-Qusyairi yakni Risalah Qusyairiyah juga memperngaruhi cara berfikir dari al-Ghazali dalam menyatakan alasannya, banyak sekali di temukan ucapan-ucapan Ibn Adham, Tustari, Muhasibi, terutama Abu Thalib al-Maliki (w.386M), pengarang Qutul Qulub dan Ibnu Hawazan al-Qusyairi (w. 465 H) pengarang Risalah Qusyairiyah (tokoh dalam bahasan ini), kedua pengarang dari kitab-kitab sufiyah yang sangat mempengaruhi cara berfikir Al-Ghazali. ${ }^{8}$

\section{Menghadapi masyarakat Multikultural dengan meneladani ajaran Al-Qusyairi}

Telah kita bahas bahwa inti dari ajaran Al-Qusyairi adalah mengembalikan doktrin-doktrin ahlussunnah wal jama'ah, dalam hal ini sangatlah penting dalam menghadapi masyarakat yang beragam, diperlukannya sikap dan perilaku yang mudah diterima di semua kalangan.

Indonesia yang merupakan Negara dengan masyarakat yang multicultural, harus bisa memahami bagaimana keadaan masyarakat dan apa yang menjadi kebutuhan dalam kesejahteraan dan ketenteraman hidup. Maka Nahdlatul Ulama' yang mengusung ajaran Ahlussunnah wal Jama'ah sudah sangat sesuai dengan apa yang dilakukan oleh Al-Qusyairi sebagai faham yang digagas oleh Imam Abul Hasan Al-Asy'ari.

Ahlussunnah wal jama'ah pada dasarnya menganut lima prinsip. Yakni, atTawazun (keseimbangan), at-Tasamuh (toleran), at-Tawasuth (moderat), atTa'adul (patuh pada hukum), dan amar makrufnahi mungkar. Dalam masalah sikap toleran pernah dicontohkan oleh pendiri NU Hadratus Syaikh KH. Hasyim Asy'ari saat muncul perdebatan tentang perlunya negara Islam atau tidak di Indonesia.

\footnotetext{
${ }^{8}$ Irwan Muhibudin, Tafsir Ayat-Ayat Sufistik (Studi Komparatif Tafsir Al-Qusyairi Dan Al-Jailani) (Jakarta: UAI Press,
} 2018). 
Kakek mantan Presiden Abdurrahman Wahid itu mengatakan, selama umat Islam diakui keberadaan dan peribadatannya, negara Islam atau bukan, tidak menjadi soal. Sebab, negara Islam bukan persoalan final dan masih menjadi perdebatan. ${ }^{9}$

Hal tersebut juga dilakukan oleh Al-Qusyairi, ketika terjadi penyimpangan yang dilakukan oleh para sufi di masa itu, mereka yang cenderung sibuk dengan dunia kesufiannya, sehingga seakan lupa dengan sekitar mereka, para sufi dengan mudah meremehkan beberapa hal yang berhubungan dengan syari'at juga dengan hubungan antara makhluk, hal tersebut membuat Al-Qusyairi berusaha mengembalikan doktrin-doktrin Aswaja, karena hal yang menyimpang sangat dikhawatirkan menjadi makna yang salah bagi masyarakat yang awam, sehingga yang terjadi adalah saling menghujat dan tidak tercipta kehidupan yang harmonis.

Al-Qusyairi juga menjelaskan bahwa tasawuf bukanlah perilaku yang menyimpang dari agama, dalam hal ini dijelasakan bahwa ada sesuatu keterikatan antara syari'at dan hakikat yang tidak bisa dipisahkan sehingga anggapan bahwa tasawuf lebih cenderung ke hakikat telah dibantah oleh Al-Qusyairi. Beliau menegaskan Syari'at adalah langkah awal dalam menuju hakikat dengan melalui jalan Thoriqoh sehingga pada akhir sampai pada maqom yang tertinggi yaitu ma'rifatulloh.

Pilar ilmu tasawuf dijelaskan oleh Al-Qusyairi antara lain

- Taqwallah (bertakwa kepada Allah) baik sewaktu sirr maupun 'alabiyah (terbuka).

- Mengikuti Sunnah baik qauli maupun fi'li serta mengaktualisasikannya dalam penjagaan diri dan akhlak yang baik.

- Berpaling dari makhluk yang diwujudkan dalam sikap sabar dan tawakkal.

- Ridho terhadap ketentuan Allah yang diwujudkan dengan sikap qona'ah dan menerima (tafwid).

- Kembali kepada Allah baik sikala senang maupun di waktu susah.

Dari pilar tersebut muncul sebuah rumusan rukun tasawuf yaitu :

\footnotetext{
${ }^{9}$ Tim Batartama Pondok Pesantren Sidogiri, Trilogi Ahlusunnah Aqidah, Syariah Dan Tasawuf (Pasuruan: Pustaka Pondok Pesantren Sidogiri, 2012).
} 
- Tajrid at-Tauhid (memurnikan tauhid).

- Memahami informasi. Maksudnya mendengar tingkah laku bukan hanya mendengar ilmu saja.

- Baik dalam pergaulan dengan siapapun.

- Mengutamakan kepentingan orang banyak ketimbang kepentingan diri sendiri.

- Meninggalkan banyak pilihan.

- Ada kesinambungan antara pemenuhan kepentingan lahir dan batin.

- Membuka jiwa terhadap intuisi (ilham).

- Banyak melakukan bepergian untuk menyaksikan keagungan alam ciptaan Tuhan sekaligus mengambil pelajaran.

- Meninggalkan iktisab untuk menumbuhkan tawakkal.

Itulah beberapa pandangan sikap-sikap yang harus ditumbuhkan sebagai muslim yang menganut faham ahlussunnah wal jama'ah sebagai bahan bagaimana seharusnya sikap yang harus kita lakukan dalam menghadapi masyarakat multicultural, sehingga prinsip dalam memegang aqidah harus kita kuatkan dalam hati tidak sampai terpengaruh dengan yang lai tetapi dalam hal social kita harus bisa menghormati dan menjalin hubungan baik dengan sesame sebagai wujud ridho terhadap ketentuan Allah. ${ }^{10}$

\section{KESIMPULAN}

Nama lengkap al-Qusyairi adalah Abdul Karim bin Hawazin. Sedangkan nasabnya adalah Abdul Karim bin Hawazin bin Abdul Malik bin Thalhah bin Muhammad sedangkan panggilannya adalah Abul Qasim. Ia lahir pada bulan Rabiul Awal tahun 376 $\mathrm{H}$ atau tahun $986 \mathrm{M}$ di Astawa.

Ia bertemu gurunya, Abu Ali al-Daqqaq di naisabur seorang sufi terkenal. Ketika mendengar ucapan ucapan ad-Daqqaq, al-Qusyairy sangat mengaguminya. Ad-Daqqaq sendiri telah berfirasat mengenai kecerdasan muridnya itu. Karena itu ad-Daqqaq mendorongnya untuk menekuni ilmu pengetahuan. Akhirnya, al Qusyairy merevisi

\footnotetext{
${ }^{10}$ Santri KH. Sholeh Bahruddin Sengonagung Purwosari Pasuruan, Sabilus Sâlikin, Jalan Para Sâlik (Ensiklopedi Tharîqah/Tashawwuf).
} 
keinginan semula, dan cita cita sebagai pegawai pemerintahan hilang dari benaknya, serta memilih jalan tarekat.

Beliau wafat di Naisabur, pada pagi hari Ahad, tanggal 16 Rablul Akhir 465 H./1073 M. Ketika itu usianya 87 tahun. Ia dimakamkan di samping makam gurunya, Syeikh Abu Ali ad-Daqqaq ra, dan tak seorang pun berani memasuki kamar pustaka pribadinya dalam waktu beberapa tahun, sebagai penghormatan atas dirinya.

Mengenai ajarannya al-Qusyairi menekankan kembali kepada Ahlus Sunnah wal Jama'ah dengan mengikuti para sufi Sunni abad ketiga dan keempat Hijriyah seperti diriwayatkan dalam Risalahnya, hal itu menunjukkan bahwa tasawuf pada masanya mulai menyimpang dari perkembangan yang pertama, baik dari segi akidah atau dari segi moral dan tingkah laku.

Dalam mengembalikan doktrin-doktrin Ahlussunnah Wal Jama'ah, Al-Qusyairi memberikan pengertian bahwa tasawuf bukanlah hal yang menyimpang dari agama, dan juga memberi penekanan terhadap hubungan syari'at, thoriqoh, hakikat hingga mencapai ma'rifat, serta memberi keteladan bagaimana sikap yang seharusnya dilakukan oleh seorang sufi yang memunculkan pilar dan rukun tasawuf. 


\section{DAFTAR PUSTAKA}

AB, Zuherni. "Sejarah Perkembangan Tasawuf." Substantia 13, no. 2 (2011): 249-256.

Fauzi, Mansur. “TASAWUF (MISTISISME).” Last modified 2018. http://mohmansurfauzi.blogspot.com/2016/11/tasawuf-mistisisme.html.

Listiana, Anisa. "Menimbang Teologi Kaum Sufi Menurut Al-Qusyairi Dalam Kitab AlRisālah Al-Qusyairiyah." Kalam: Jurnal Studi Agama dan Pemikiran Islam Vol. 7, no. 1 Juni (2013): 201-216.

Muhibudin, Irwan. Tafsir Ayat-Ayat Sufistik (Studi Komparatif Tafsir Al-Qusyairi Dan AlJailani). Jakarta: UAI Press, 2018.

Ronika, Rima. "CORAK AJARAN TASAWUF DALAM PÊPALI KI AGÊNG SELO DITINJAU DARI PERSPEKTIF HERMENEUTIK FRIEDRICH DANIEL ERNST SCHLEIERMACHER.” Jurnal filsafat dan pemikiran islam Vol. 19, no. 2 Juli (2019).

Rosidi. "Konsep Maqomat Dalam Tradisi Sufistik KH. Ahmad Asrori Al-Ishaqy." Jurnal Tasawuf dan Pemikiran Islam Vol. 4, no. 1 Juni (2014): 29-55.

Santri KH. Sholeh Bahruddin Sengonagung Purwosari Pasuruan. Sabilus Sâlikin, Jalan Para Sâlik (Ensiklopedi Tharîqah/Tashawwuf). Pasuruan: Pondok Pesantren NGALAH, 2012.

Tim Batartama Pondok Pesantren Sidogiri. Trilogi Ahlusunnah Aqidah, Syariah Dan Tasawuf. Pasuruan: Pustaka Pondok Pesantren Sidogiri, 2012. 